\title{
Phenomic characterization of Crotalaria germplasm for crop improvement
}

\author{
Joshua Kiilu Muli ${ }^{1}$ (D), Johnstone O. Neondo $2^{*}$ (D) Peter K. Kamau ${ }^{3}$ (D), Eddy Odari ${ }^{4}$ (D) \\ and Nancy L. M. Budambula ${ }^{1}$ (D)
}

\begin{abstract}
Background: Diversification of global food systems through exploration of traditional varieties and wild edible plant species is a focal mitigation strategy for food security worldwide. The present study determined the phenomic diversity of locally available, affordable and climate-resilient cultivated and wild Crotalaria species for breeding purposes.

Methods: Seed samples were collected from different administrative counties in Kenya spanning different climatic zones. Other seeds were provided by the Genetic Resources Research Institute of Kenya. A randomized complete block design with three replications was used for agro-morphological evaluation of the 83 accessions used in this study. Data on quantitative and qualitative traits was collected. Cluster analysis on R and R-studio was used to generate a dendrogram by the Euclidian genetic distance and dissimilarity indices while the non-metric multidimensional scaling (NMDS) method was used to determine the spatial interrelationship between the accessions. The Pearson's correlation coefficients were used to determine the relationships between qualitative and quantitative traits while the principal component analysis was used to discriminate the accessions.
\end{abstract}

Results: Three edible species (C. brevidens Benth., C. ochroleuca G.Don, C. trichotoma Bojer.) were found to be cultivated by Kenyan farmers and a significant variation $(p<0.0001)$ for all parameters under study was recorded. Agglomerative hierarchical clustering grouped the accessions into 8 major clusters. The NMDS ordination formed 15 and 6 groups based on counties and regions respectively.

Conclusions: This study forms the basis for exploring novel breeding strategies among cultivated species, between wild and cultivated Crotalaria species as well as determining molecular markers linked to phenomic traits.

Keywords: Crotalaria, Germplasm, Agro-morphology, Genetic diversity

\section{Background}

The world food supply is increasingly under threat due to climate change, population explosion and crop destruction by pests and diseases. The creation, operation, and evolution of 'new' or 'alternative' food supply chains is one of the key mitigation strategies of achieving global food security (Renting et al. 2003). A critical dimension of this strategy is the conservation of genetic diversity of

\footnotetext{
*Correspondence: jneondo@jkuat.ac.ke

${ }^{2}$ Institute for Biotechnology Research, Jomo Kenyatta University of Agriculture and Technology, P.O Box 62000, 00200 Nairobi, Kenya

Full list of author information is available at the end of the article
}

plant species to safeguard potential economic traits that could be vital in combating pests infestations and diseases outbreaks as well as increasing crop yields (Pandey et al. 2019). Plant breeders rely on genetic diversity of plants to improve yield, resistance to pests and diseases, and tolerance to environmental stress (Govindaraj et al. 2015). Plants respond to changing environments through phenotypic plasticity derived from both genetic and epigenetic factors. Epigenetic variation has been associated with a wide range of adaptive phenotypes in plants, but few direct means for exploiting this variation exist (Raju et al. 2018).

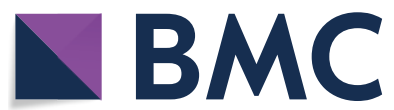

c) The Author(s) 2021. This article is licensed under a Creative Commons Attribution 4.0 International License, which permits use, sharing, adaptation, distribution and reproduction in any medium or format, as long as you give appropriate credit to the original author(s) and the source, provide a link to the Creative Commons licence, and indicate if changes were made. The images or other third party material in this article are included in the article's Creative Commons licence, unless indicated otherwise in a credit line to the material. If material is not included in the article's Creative Commons licence and your intended use is not permitted by statutory regulation or exceeds the permitted use, you will need to obtain permission directly from the copyright holder. To view a copy of this licence, visit http://creativeco mmons.org/licenses/by/4.0/. The Creative Commons Public Domain Dedication waiver (http://creativecommons.org/publicdomain/ zero/1.0/) applies to the data made available in this article, unless otherwise stated in a credit line to the data. 
Morphological characterization is essential in the identification of valuable germplasm accessions as well as typification and classification of accessions into cultivar groups. Morphological characterization using conventional phenomic descriptors (morphological and agronomic descriptors) is cardinal in describing and establishing relationships among cultivar groups and accessions of genetically un-profiled crops (Plazas et al. 2014). Availability of genetic diversity within crop plants in the form of wild species, mutant lines or even breeding stocks serves as a source of important alternative gene forms and could therefore help in development of climate tolerant varieties (Fu 2015). Since breeding goals are constantly changing, there is need to introgress different genes in both domesticated and semi-domesticated crops either as germplasm resources or otherwise (Bhandari et al. 2017).

The Genus Crotalaria L. consists of more than 600 species of herbs and shrubs distributed in the tropical and sub-tropical regions (Pandey et al. 2010). The greatest diversity in the genus is found in Africa, which has over 400 species (Abukutsa-Onyango 2007). Plants in this genus have a myriad of uses including ethno-medicinal uses, nitrogen fixation, green manure, silage, fiber, cover crop for weeds control, prevention of soil erosion, control of nematodes and as ornamental plants (Ramos et al. 2001; Rouamba et al. 2018). In Kenya, some Crotalaria species have been used in the control of the parasitic weed Striga hermonthica and as food (Rouamba et al. 2018). Despite their potential, these species have continued to receive little attention in terms of research and improvement and as such, their diversity remains unknown (Wang et al. 2006). In Kenya, there are only two documented edible Crotalaria species with scanty information on their agro-morphological description (Sahou et al. 2014). A common challenge for Crotalaria collection holders is the lack of characterization and evaluation data, without which, the genetic material is not readily usable. Detailed plant genetic diversity that is aligned to plant phenomic profiles is essential in plant breeding and subsequently genetic improvement. This study documents the phenomic diversity of cultivated and wild Crotalaria species, to the information published herein is essential in enhancing understanding of the diversity within and among Crotalaria accessions. Such diversity is relevant for classification, management of genetic resources, selection and breeding, as well as, for research purposes.

\section{Methods}

Description of study sites, sample collection criteria and processing

Study samples were collected from all the three Kenyan climatic regions of agricultural importance namely; the hot and humid coastal strip, the temperate zone covering the west and south west regions with mountains and plateaus, and lastly the hot and dry north and eastern zone. These regions have considerable variations in rainfall and temperature. The arid and semi-arid zones record rainfall ranges of between 200 and $600 \mathrm{~mm}$ with temperature ranges of $23{ }^{\circ} \mathrm{C}$ to $34{ }^{\circ} \mathrm{C}$. The coastal belt experiences rainfall ranging between 1000 and $1250 \mathrm{~mm}$ with temperature ranges of $22{ }^{\circ} \mathrm{C}$ to $30{ }^{\circ} \mathrm{C}$ while the temperate zone receives rainfall ranging $950 \mathrm{~mm}$ to $3000 \mathrm{~mm}$ with temperature ranges of $14{ }^{\circ} \mathrm{C}$ to $28^{\circ} \mathrm{C}$ annually. Three hundred farmer-held Crotalaria accessions were collected from the fore-mentioned zones and 133 Crotalaria accessions were cordially provided by the Genetic Resources Research Institute of Kenya (GBK). All the accessions were established in field and green house conditions at the University of Embu Farm and used to establish the working germplasm stock (Fig. 1). During this period the germplasms were continuously monitored and morphological information about these accessions noted for purposes of later clustering them into groups based on their morphological characteristics and reduce duplication. After this grouping, similar genotypes were pooled together and the working stock reduced from 433 accessions to 83. Global positioning system (GPS) coordinates for all sampled sites were recorded and used to generate a geo-spatial map (Fig. 2) using the ArcGIS 10.5 software. To establish the demographics of cultivated Crotalaria in Kenya, a purposive non-probability sampling involving the snowball technique of Crotalaria farmers was employed in the regions where the crop is cultivated. Data on cultivation and utility aspects were collected from the respondents who cultivated and utilised the crop using structured questionnaires.

\section{Cultivation, characterization and classification}

Sampled seeds were planted in the research field and the plants were continuously monitored. Individual plants in an accession were characterized morphologically using 18 plant descriptors. The descriptors were; plant height, number of leaflets, leaf length, leaf breadth, leaf area, pod length, pod breadth, number of branches and number of pods per plant (quantitative variables) and stem colour, life span, growth habit, leaf/leaflet shape, stem pubescence, corolla colour, dry pod colour, seed colour and pod shape (qualitative variables) as described by Raj and Britto (2011). The data was used to cluster the 83 


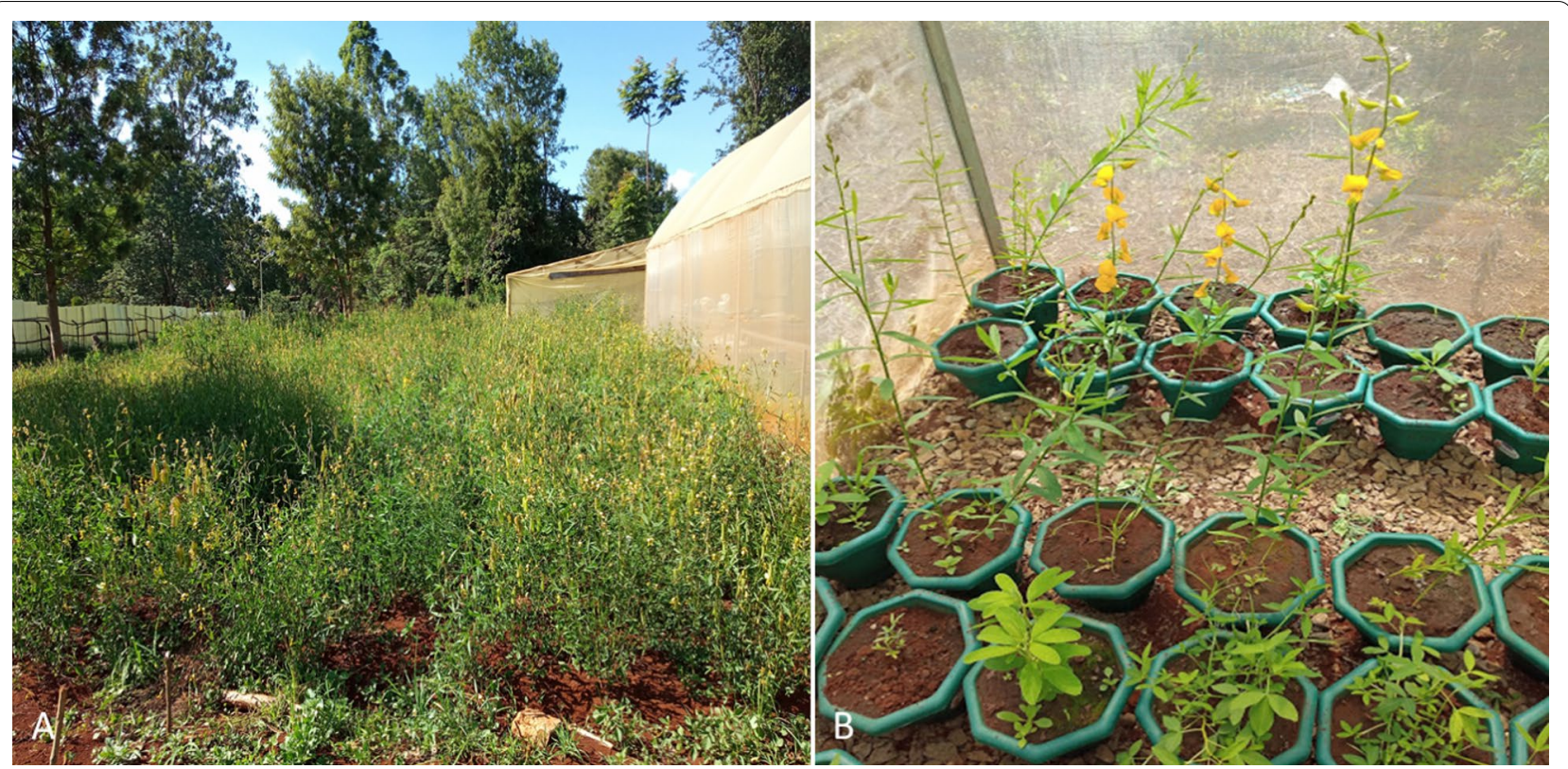

Fig. 1 Established Crotalaria accessions at the research fields and green house conditions. Crotalaria accessions established in the field (a) and green house (b) before establishment of germplasm stock

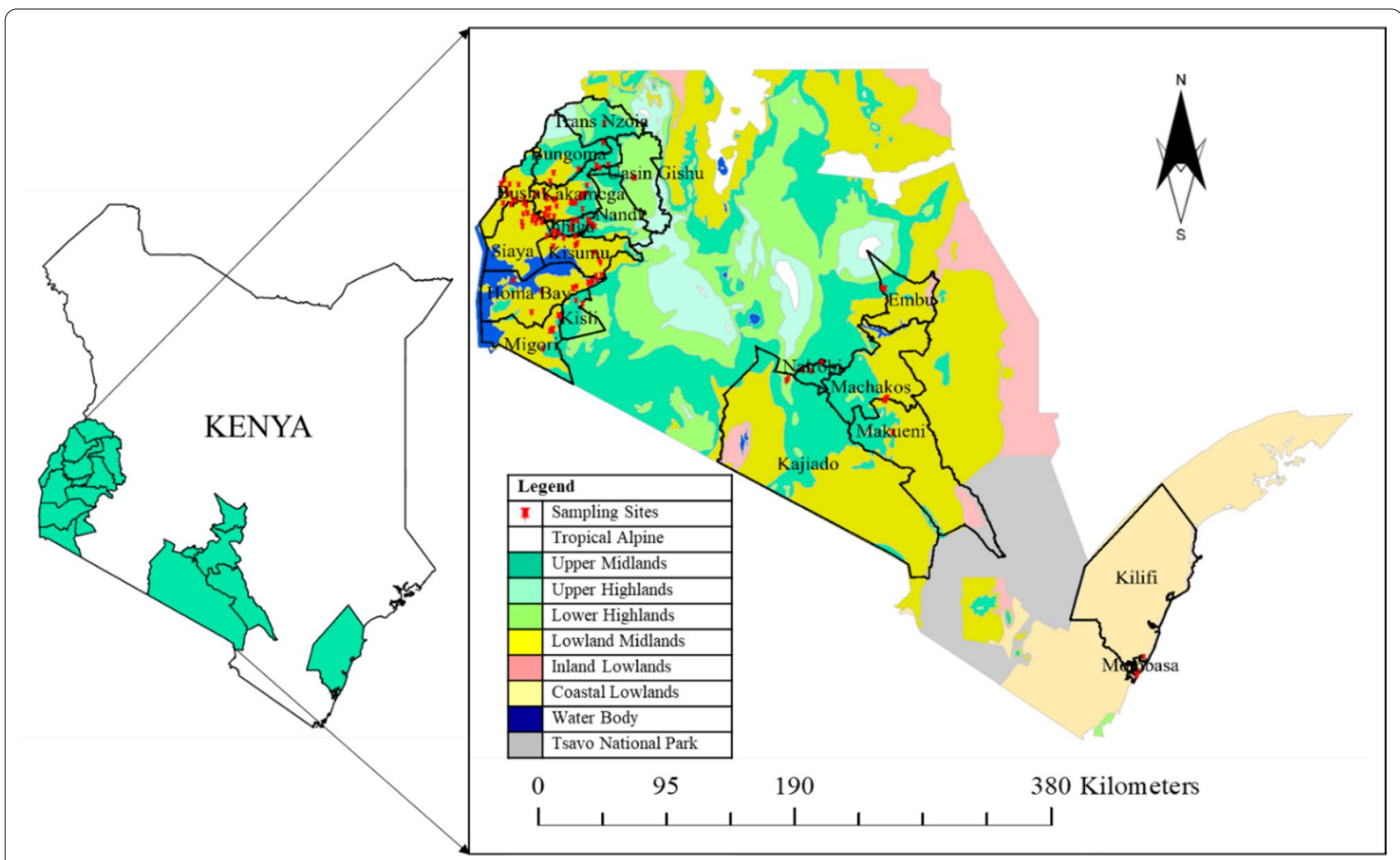

Fig. 2 Kenyan agro-ecological zones and the Crotalaria sampling sites 
accessions based on similarities of these morphological characteristics.

\section{Experimental design}

Agro-morphological evaluation of the 83 accessions was done using the randomized complete block design (RCBD) with three replications. Each accession was planted in a single line in each block. Seeds were then directly sown in rows of $4 \mathrm{~m}$ long and $45 \mathrm{~cm}$ apart (Sadiq et al. 2019). Thinning was done after four weeks of establishment to ensure an intra row spacing of $30 \mathrm{~cm}$ and a single plant for each sample per block randomly selected for data collection. All farm practices were adhered to except fertilizer or manure application.

\section{Data analysis}

Questionnaire data was analysed using the Statistical Product and Service Solutions (SPSS) software version 20. Quantitative data of the study including the analysis of means of the different parameters under study as well as correlation analysis was subjected to ANOVA using the Statistical Analysis Software (SAS version 6.2.9), and mean separation done using the Student Newman Keuls (SNK) test at $95 \%$ and $99 \%$ confidence levels. Quantitative and qualitative data were organized into a matrix and analysed using $\mathrm{R}$ and RStudio packages (Versions 3.6.2 and 1.2.5 respectively). The Euclidean genetic distance and dissimilarity indices were used to estimate similarity and generate a dendrogram using the Unweighted PairGroup Method with Arithmetic average (UPGMA) in R-studio. Non-metric multidimensional scaling (NMDS) method was used to determine the spatial interrelationship between the samples based on the administrative regions (counties) from where they were collected as well as their agro-ecological regions of origin (regions). A two-dimension model with 999 permutations per run was generated using metaMDS in Vegan for NMDS in $\mathrm{R}$ (McCune and Grace 2002). The principal component analysis (PCA) was used to discriminate accessions while the cluster analysis was used to group them based on their quantitative parameters in R-studio. Pearson's correlation coefficients were used to determine the relationship between quantitative traits. A heat map was used to visually represent the contributions of the different parameters to the observed morphological diversity.

\section{Results}

Availability and distribution of Crotalaria species in Kenya The present study determined that there are 21 morphologically distinct Crotalaria species distributed in 15 counties in Kenya (Additional file 1: Table S1) with three species already domesticated by two communities in the country. These species were predominantly found in Kakamega, Vihiga, Busia, Bungoma, Kisumu, Migori, Siaya and Homa Bay counties. Only 9 of 133 accessions (6.77\%) provided by the Genetic Resources Research Institute of Kenya are domesticated by local communities in Kenya, and belonged to the species $C$. brevidens Benth and C. trichotoma Bojer.

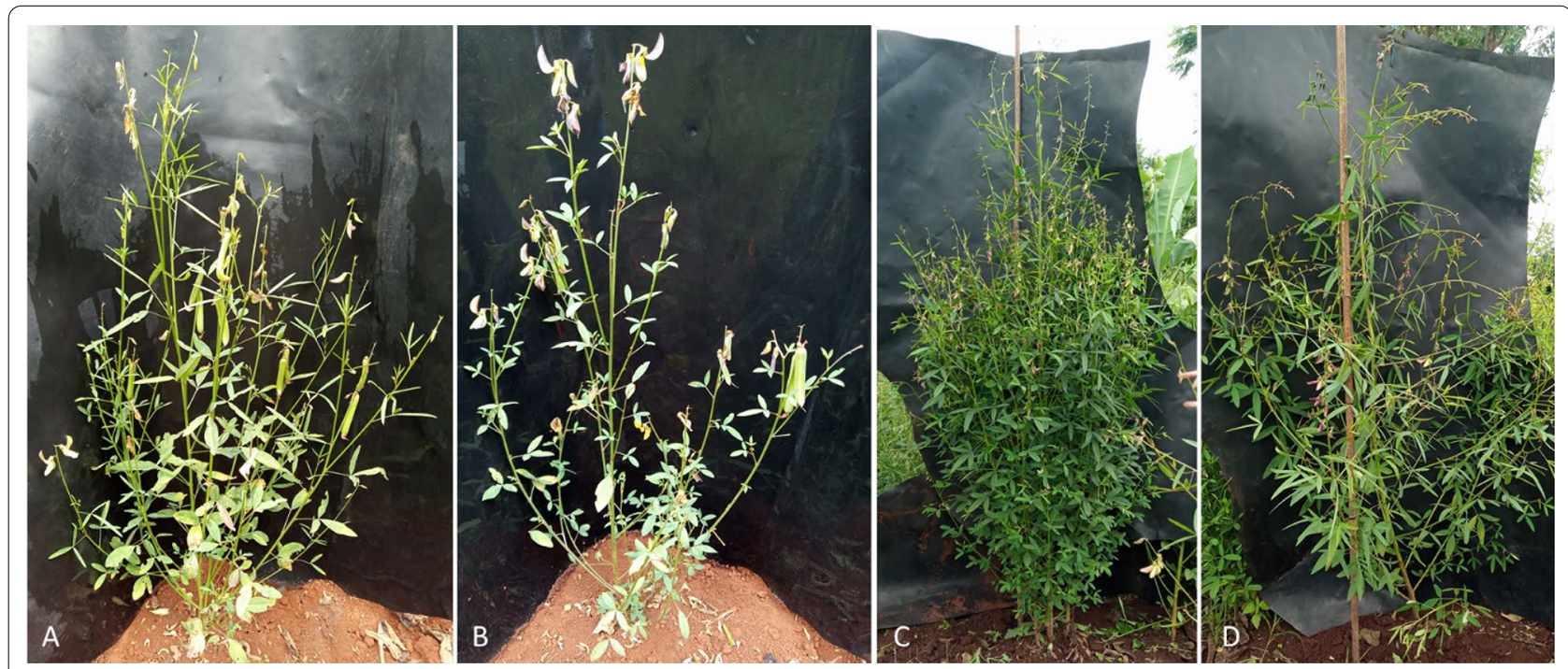

Fig. 3 Edible Crotalaria species in Kenya. a C. brevidens Benth. var. intermedia. With bright green leaves and slender pods. b C. brevidens Benth. var. brevidens. With dull green leaves and slender pods. c C. ochroleuca G.Don with many branches and broad podded. d C. trichotoma Bojer which is taller, less branching and with broad pods 


\section{Edible Crotalaria species in Kenya}

Three Crotalaria species were found to be cultivated by farmers in Kenya (Fig. 3). These are C. brevidens Benth. var. brevidens, C. brevidens Benth. var. intermedia, C. ochroleuca G.Don. and C. trichotoma Bojer./C. zanzibarica Benth. Morphologically these three species closely resemble one another but with a few differences. C. brevidens Benth. var. brevidens and C. brevidens Benth var. intermedia both have slender pods at maturity compared to $C$. ochroleuca and C. trichotoma which have relatively broad pods. The calyx of $C$. brevidens Benth are relatively puberulous with bright yellow petals while those of $C$. ochroleuca, and C. trichotoma are glabrous with pale yellow petals. The difference between the two varieties of C. brevidens is the colour of leaflets which are dull green in C. brevidens Benth. var. brevidens and bright green in Crotalaria brevidens Benth. var. intermedia. C. trichotoma, sometimes referred to as C. zanzibarica is an erect herb which grows taller than the other three (up to $2.70 \mathrm{~m}$ ) with a woody base. It is morphologically close to C. ochroleuca which is relatively shorter (up to $2.50 \mathrm{~m}$ ) but highly branching. C. ochroleuca, and C. trichotoma have a mild taste while $C$. brevidens have a bitter taste although the degree of bitterness depends on the place and time of propagation. Out of the 83 accessions used in this study, 28 (33.7\%) were C. ochroleuca, 4 (4.8\%) were C. trichotoma and 11 (13.3\%) were C. brevidens.

\section{Cultivation aspects of Crotalaria vegetables}

From a sampled population of 37 farmers, 86.5\% knew of two types of edible Crotalaria species, $10.8 \%$ knew of three types while $2.7 \%$ did not know of the different types. However, this was based on the taste of cooked vegetables, which they categorized as either mild, bitter or very bitter. Edible Crotalaria species in Kenya were found to be cultivated by small holder farmers, with land sizes ranging from 0.20 to 8.0 hectares. The crop was mainly cultivated in kitchen gardens with average land size under the crop observed of 0.058 ha. Of the farmers interviewed, $89.2 \%$ planted the crop in less than 0.05 ha (Additional file 2: Table S3). A correlation analysis of farm size and the total land area under Crotalaria vegetables revealed that there was a positive correlation between household size and the portion under which Crotalaria vegetables were grown $\left(r^{2}=0.17\right)$ although not significant $(p=0.314)$. Farm size and the portion of land under Crotalaria vegetables were positively correlated $\left(\mathrm{r}^{2}=0.665, \mathrm{p}=0.001\right)$ (Additional file 3: Table S4). Analysis of variance revealed that there was a significant difference in the portions of land under the crop among all the interviewed farmers $(p=0.001)$, with the largest being 0.8 ha and the least being less than 0.05 ha. Household sizes for the interviewed farmers ranged from two to eight people and this was found to have an effect on how much piece of land will be cultivated to plant Crotalaria vegetables, with large households cultivating more land than the small households.

It was observed that $89.2 \%$ of the farmers who cultivated crotalaria vegetables were aged between 31 and 65 years with none of the respondents aged between 0 and 30 years. Only $6(16.2 \%)$ of the 37 respondent farmers who cultivated Crotalaria vegetables had formal education beyond the secondary level. All the farmers with tertiary education planted the vegetable for commercial and domestic purposes. However, 15 (40.5\%) farmers with primary and secondary education planted the vegetables solely for domestic consumption. Majority (70.3\%) of the farmers admitted to eating the vegetable weekly, while 4 farmers (1.2\%) ate the vegetable daily and fortnightly. Of all the interviewed farmers, only 5 (13.5\%) were male, while 32 were female, representing $86.5 \%$.

\section{Variation in quantitative characters in Kenyan Crotalaria species}

Significant variations $(\mathrm{p}<0.0001$ for all parameters) between accessions were recorded for all the quantitative variables; height, number of leaflets, leaf length, leaf width, number of branches, pod length, pod diameter, pods per plant and leaf area (Additional file 4: Table S2). Mean height ranges were between $265 \mathrm{~cm}$ in sample GBK-005664 (C. trichotoma) and $34 \mathrm{~cm}$ in sample GBK005489 (C. greenwayi). From the 83 samples used in this study, 76 had compound leaves with three leaflets except for C. grahamiana which had seven leaflets. The other seven samples had simple leaves, representing the five species; C. juncea, C. spectabillis, C. retusa, C. paulina and C. pancira. Leaf lengths ranged from $19.0 \mathrm{~cm}$ in sample GBK-005209 (C. paulina) to $1.13 \mathrm{~cm}$ in sample GBK005664 (C. greenwayi). The leaf area followed the same pattern, with sample GBK-005209 (C. paulina) having the largest leaf area $\left(122.51 \mathrm{~cm}^{2}\right)$ and GBK-005664 $(C$. greenwayi) with the smallest leaf area $\left(0.606 \mathrm{~cm}^{2}\right)$. The most profuse branching was observed in samples GBK005685 (C. spectabilis) and GBK-005201 (C. pancira) which had a mean of 34.33 branches while the least number of branches observed in sample Fmg 0298 (C. pallida) with a mean of 3.00 branches. The mean pod length ranged from $6.7 \mathrm{~cm}$ in sample Fvh 0119 to $0.4 \mathrm{~cm}$ in sample GBK-047548 (C. cephalotes) while mean pod diameter ranged from $5.83 \mathrm{~cm}$ in sample Fvh 0119 to 0.90 in sample GBK-005664 (C. greenwayi). Sample GBK-005189 (C. laburnifolia) had the highest mean number of pods while Fki 0123 (C. ochroleuca) had the least mean number of pods. 


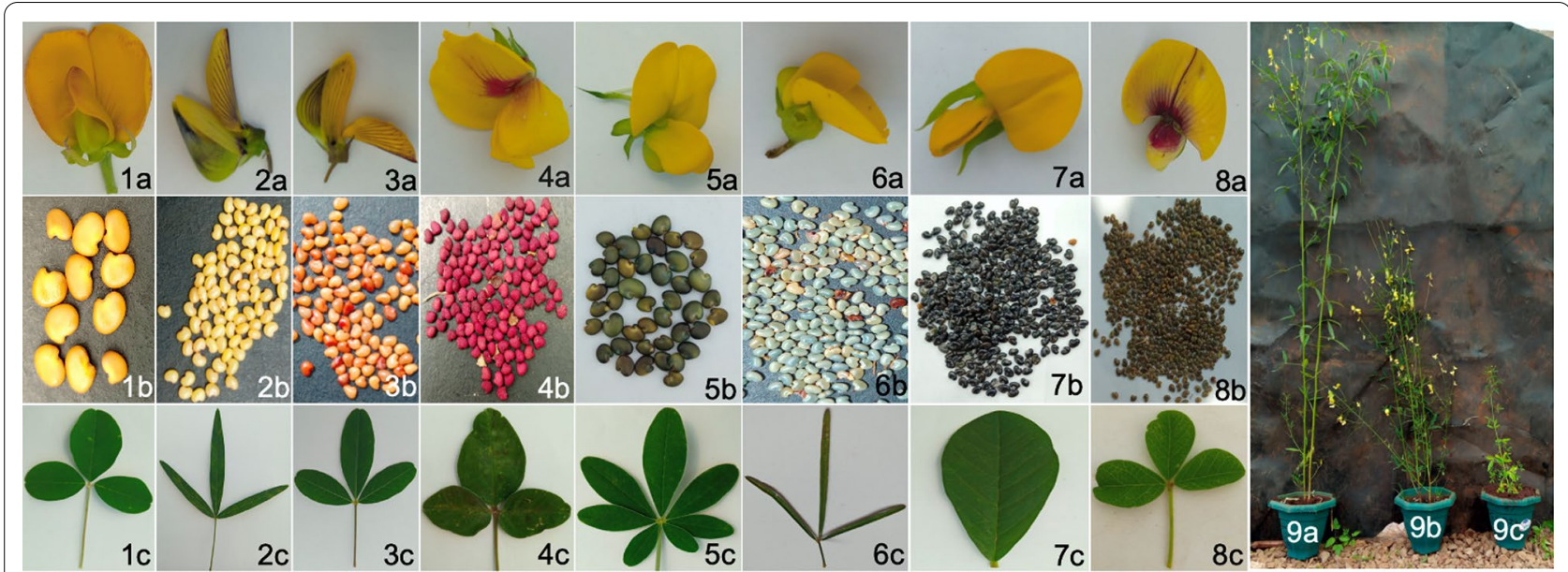

Fig. 4 Qualitative and quantitative characters of different Crotalaria species in Kenya. Qualitative [petal colours (a), seed colours (b) and leaf shapes (c)]. Quantitative [plant height (9a 1.95 m, 9b 1.10 m, 9c 0.9 m)]. (1) C. scassellatii, (2) C. ochroleuca, (3) C. brevidens, (4) C. endecaphyla, (5) C. grahamiana, (6) C. trichotoma, (7) C. spectabilis, (8) C. intermedia. 9a C. trichotoma. $\mathbf{9 b} / \mathbf{c}$ C. ochroleuca

\section{Variation in qualitative characters}

The qualitative characters that were studied include; leaf shape, pod shape, leaf type, flower colour, stem colour, hairiness of the stem, dry pod colour, seed colour and growth habit (Fig. 4). There were 6 leaf shapes observed within the genus, of which three were observed in 74 accessions, accounting for $89.1 \%$ of the shape diversity observed. Oblanceolate leaves/leaflets were the most common and were observed in 27 (32.5\%) samples, followed by the elliptical 25 (30.1\%) and linear 22 (26.5\%). The obovate, orbicular and ovate leaves/leaflets constituted $5(6 \%), 2(2.4 \%)$ and $2(2.4 \%)$ accessions respectively. The long broad smooth pod was the most frequent and was observed in 49 (59\%) accessions, followed by the long slender smooth, observed in $22(26.5 \%)$ accessions. The long broad hairy, short broad hairy and short slender smooth pods were the lest frequent, with each constituting $1.2 \%$. The short broad smooth and long slender hairy pods constituted $7.2 \%$ and $3.6 \%$ respectively. The compound leaf type was observed in 76 (91.6\%) accessions while $7(8.4 \%)$ accessions had simple leaves. The pale yellow corolla with purple stripes were observed in 29 (34.9\%) samples while the deep yellow with purple stripes were observed in 15 (18.1\%) samples. The lemon yellow corolla with purple stripes and the chartreuse yellow were the least, representing only $1.2 \%$ of the samples. The brown-green stems were the most abundant in the population $(51.8 \%)$, while green and pale green were $14.5 \%$ and $13.3 \%$ respectively. Purple-green and shinygreen stems each represented $6 \%$ of the samples. Darkgreen and yellow-green stems were the least abundant in the samples representing $4.8 \%$ and $3.6 \%$ respectively. The stems were either smooth $(75.9 \%)$ or pubescent
(24.1\%). Black dry pods constituted 63.9\% while brown dry pods represented $33.7 \%$. Brown with black striped pods and green with brown striped pods were $1.2 \%$ each. Pale-yellow seeds were the majority (32.5\%), while the mixture of pale-yellow and red-orange, and the purely red-orange seeds constituted $16.9 \%$. Other seed colours observed were black (6\%), brown $(7.2 \%)$, grey $(6 \%)$, pale grey $(2.4 \%)$, black and grey mixture $(2.4 \%)$, grey and paleyellow mixture (1.2\%) striped grey (3.6\%), maroon $(2.4 \%)$ and purple (2.4\%). Most of the cultivated accessions had mixed seed colours in a pod whereas the wild species had distinct uniform seed colours.

Qualitative [petal colours (a), seed colours (b) and leaf shapes (c)]. Quantitative [plant height (9a. $1.95 \mathrm{~m}, 9 \mathrm{~b}$. $1.10 \mathrm{~m}, 9$ c. $0.9 \mathrm{~m}$ )]. (1) C. scassellatii, (2) C. ochroleuca, (3) C. brevidens, (4) C. endecaphyla, (5) C. grahamiana, (6) C. trichotoma, (7) C. spectabilis, (8) C. intermedia. (9a) C. trichotoma (9b/c) C. ochroleuca.

\section{Correlation between quantitative variables}

A weak positive correlation was observed between height and the following traits: number of leaflets, number of branches, pod length, pod diameter and the number of pods per plant (Table 1). Height and leaf length had no correlation. However, height only correlated significantly with the number of leaflets, $\left(r^{2}=0.158\right.$, $\mathrm{p}=0.0128)$, number of branches $\left(\mathrm{r}^{2}=0.160, \mathrm{p}=0.0111\right)$, pod length $\left(\mathrm{r}^{2}=0.191, \mathrm{p}=0.0024\right)$ and pod diameter $\left(r^{2}=0.125, p=0.0481\right)$. Both leaf width $\left(r^{2}=-0.170\right.$, $\mathrm{p}=0.007)$ and leaf area $\left(\mathrm{r}^{2}=-0.149, \mathrm{p}=0.018\right)$ had $\mathrm{a}$ significant inverse correlation with height. All parameters correlated negatively with the number of leaflets except pod length $\left(r^{2}=0.192, p=0.002\right)$ and pods per 
Table 1 Correlation of nine quantitative traits of 83 Crotalaria accessions from Kenya

\begin{tabular}{|c|c|c|c|c|c|c|c|c|c|}
\hline Variable & Height (cm) & No. of leaflets & $\begin{array}{l}\text { Leaf length } \\
(\mathrm{cm})\end{array}$ & $\begin{array}{l}\text { Leaf width } \\
(\mathrm{cm})\end{array}$ & $\begin{array}{l}\text { Number of } \\
\text { branches }\end{array}$ & $\begin{array}{l}\text { Pod length } \\
(\mathrm{cm})\end{array}$ & $\begin{array}{l}\text { Pod diameter } \\
(\mathrm{cm})\end{array}$ & $\begin{array}{l}\text { Pods per } \\
\text { plant }\end{array}$ & $\begin{array}{l}\text { Leal area } \\
\left(\mathrm{cm}^{2}\right)\end{array}$ \\
\hline Height (cm) & 1.00000 & & & & & & & & \\
\hline No. of leaflets & $0.15752^{* * *}$ & 1.00000 & & & & & & & \\
\hline $\begin{array}{l}\text { Leaf length } \\
(\mathrm{cm})\end{array}$ & 0.04413 & $-0.42131^{* * *}$ & 1.00000 & & & & & & \\
\hline $\begin{array}{l}\text { Leaf width } \\
(\mathrm{cm})\end{array}$ & $-0.17014^{* * *}$ & $-0.43052^{* * *}$ & $0.5311^{* * *}$ & 1.00000 & & & & & \\
\hline $\begin{array}{l}\text { Number of } \\
\text { Branches }\end{array}$ & $0.16074^{* * *}$ & -0.09821 & $0.29659^{* * *}$ & 0.00957 & 1.00000 & & & & \\
\hline $\begin{array}{l}\text { Pod length } \\
(\mathrm{cm})\end{array}$ & $0.19154^{* * *}$ & $0.19164^{* * *}$ & $0.24146^{* *}$ & -0.05292 & $0.15774^{* * *}$ & 1.00000 & & & \\
\hline $\begin{array}{l}\text { Pod diameter } \\
(\mathrm{cm})\end{array}$ & $0.12537^{* *}$ & -0.01905 & $0.22668^{* *}$ & 0.07796 & $0.21449^{* *}$ & $0.65484^{* * *}$ & 1.00000 & & \\
\hline $\begin{array}{l}\text { Pods per } \\
\text { plant }\end{array}$ & 0.11343 & 0.07467 & $0.2005^{* *}$ & $0.179^{* * *}$ & $0.22013^{* * *}$ & -0.00918 & $-0.25797^{* * *}$ & 1.00000 & \\
\hline $\begin{array}{l}\text { Leaf area } \\
\left(\mathrm{cm}^{2}\right)\end{array}$ & $-0.14985^{* *}$ & $-0.56131^{* * *}$ & $0.74386^{* * *}$ & $0.88564^{* * *}$ & $0.15342^{* * *}$ & -0.00792 & 0.10351 & $0.1971^{* *}$ & 1.0000 \\
\hline
\end{tabular}

**Values are different from 0 at a significance level of $p<0.05$

$* * *$ Values are different from 0 at a significant level of $p<0.01$

plant $\left(\mathrm{r}^{2}=0.074, \mathrm{p}=0.240\right)$. Among the negatively correlating parameters, a moderate negative correlation was observed only between the number of leaflets and leaf area $\left(r^{2}=-0.561\right)$, which was significantly different $(\mathrm{p}<0.0001)$. Although leaf length and leaf width were moderately negatively correlating with number of leaflets, this correlation was significantly different with $\mathrm{p}<0.0001$ for both parameters. Leaf length correlated positively with all the other parameters. However, only leaf area $\left(\mathrm{r}^{2}=0.74 ; \mathrm{p}<0.0001\right)$ and had strong positive correlations with leaf length, with leaf width $\left(r^{2}=0.531 ; p \leq 0.0001\right)$, number of branches $\left(r^{2}=0.297\right.$, $\mathrm{p} \leq 0.0001)$, pod length $\left(\mathrm{r}^{2}=0.241, \mathrm{p}=0.0001\right)$, pod diameter $\left(\mathrm{r}^{2}=0.227, \mathrm{p}=0.0003\right)$ and pods per plant $\left(\mathrm{r}^{2}=0.201, \mathrm{p}=0.0015\right)$ all showing moderate to weak positive correlations. Leaf width had no correlation with pod length $\left(\mathrm{r}^{2}=-0.052, \mathrm{p}=0.4057\right)$, but had positive correlation with all the other parameters. However, only leaf area strongly correlated with leaf width, $\left(r^{2}=0.886\right.$, $\mathrm{p}<0.0001$ ). The number of branches had a positive weak correlation which was significantly different from zero with the following parameters: pod length $\left(r^{2}=0.157\right.$, $\mathrm{p}=0.013)$, pod diameter $\left(\mathrm{r}^{2}=0.214, \mathrm{p}=0.0007\right)$, pods per plant $\left(r^{2}=0.220, p=0.0005\right)$ and leaf area $\left(r^{2}=0.153\right.$, $\mathrm{p}=0.015)$. Pod length had a significantly moderate positive correlation with pod diameter $\left(\mathrm{r}^{2}=0.654, \mathrm{p}<0.0001\right)$ but had no correlation with pods per plant and leaf area. Pod diameter and pods per plant were weakly negatively correlated, which was significantly different from zero $\left(\mathrm{r}^{2}=-0.257, \mathrm{p}<0.0001\right)$. A significant weak positive correlation was observed between pods per plant and leaf area $\left(\mathrm{r}^{2}=0.197, \mathrm{p}=0.0018\right)$.

\section{Agglomerative hierarchical clustering of qualitative and quantitative traits}

Agglomerative hierarchical clustering of both qualitative and quantitative traits of the 83 Crotalaria accessions assembled them into eight major clusters at 7.5 Euclidean distance (Fig. 5, Additional file 5: Table S5). The first cluster (A) had only one wild accession, C. spectabilis. The distinct feature of this accession was the simple leaf type with the highest leaf area index. The second cluster (B) consisted of four wild accessions of different species with two sub-clusters. The first sub-group consisted of the species $C$. incana and $C$. endecaphylla while the second consisted of $C$. cephalotes and $C$. greenwayi species. All these species have trifoliate compound leaves and other similarities in qualitative traits such as brown dry pods and hairy stems. The third cluster $(\mathrm{C})$ comprised three wild accessions representing two species; $C$. juncea and C. greenwayi. These species are herbaceous with brown dry pods. Cluster four (D) consisted of four wild accessions with four different species; C. spectabilis, C. retusa, C. pancira and C. paulina. These accessions are perennial shrubs with simple leaves, their dry pods are brown with black or grey seeds and have shiny green stems. Cluster five (E) was made up of 14 accessions representing 10 species. All the accessions in this cluster were wild perennial shrubs with compound leaves. The first sub-group consisted of five accessions of the species C. pallida, $C$. 


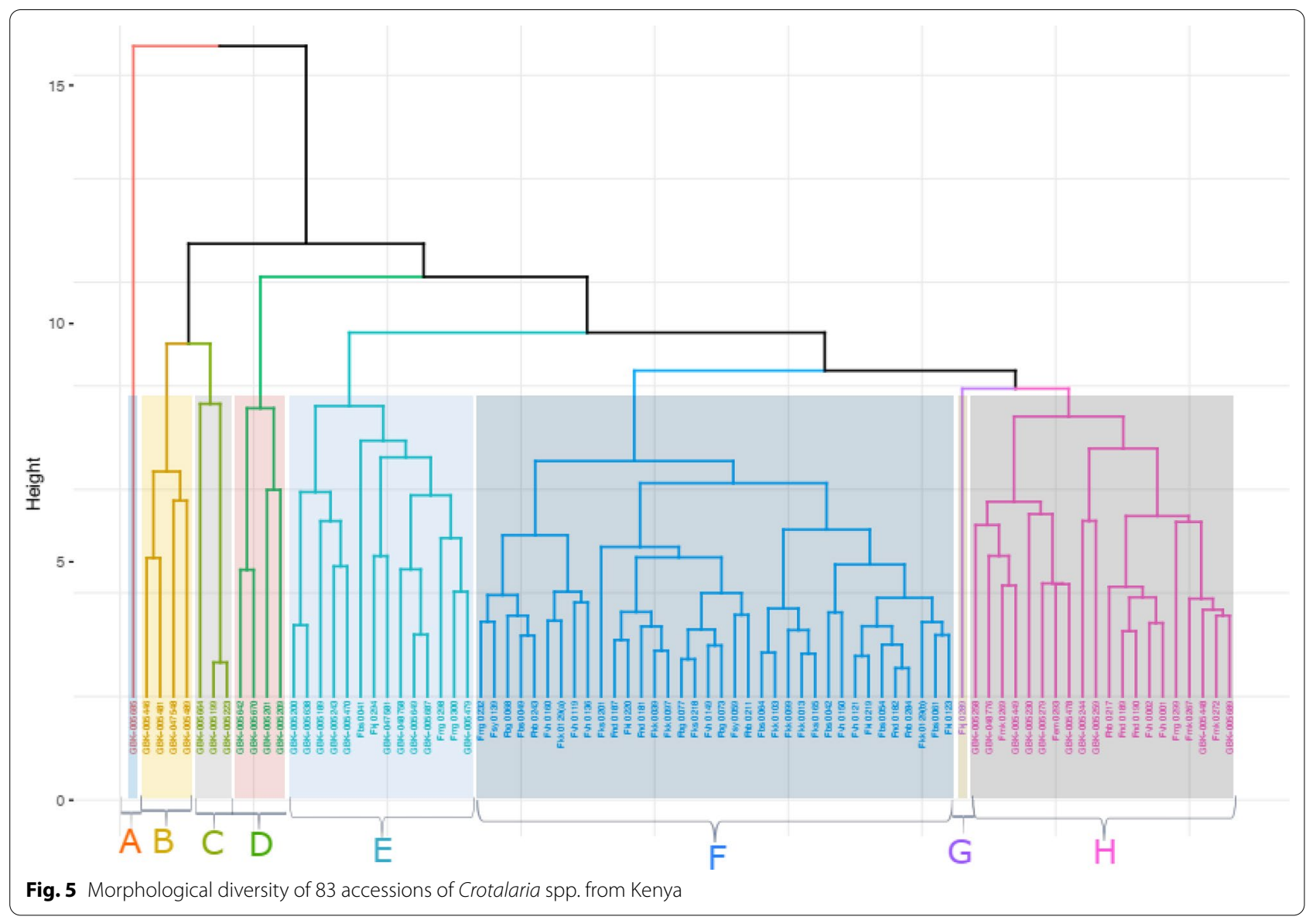

laburnifolia, C. intermedia and C. anagyroides, all with three leaflets and brown dry pods. The other sub-group in this cluster consisted of a single accession of the species C. grahamiana which has seven leaflets. The other sub-cluster in the group consisted of two accessions namely; C. scassellatii and accession Fkj 0294 (collected from Kajiado county). The last sub-cluster in this group consisted of six accessions, representing only two species; C. recta, and C. endecaphylla, characterised by compound trifoliate leaves and black dry pods. The sixth cluster (F) consisted of 36 cultivated accessions. A common feature among these accessions is that their dry pods are black, and their flowers have purple stripes. The cluster consisted of the two species, C. brevidens and C. ochroleuca. This cluster had three sub-clusters, two entirely made of C. ochroleuca samples while the third consisted of a mixture of $C$. brevidens and C. ochroleuca accessions. The Seventh cluster (G) consisted of the wild type perennial herb $C$. intermedia. The last cluster $(\mathrm{H})$ was made up of 20 accessions, comprising of both cultivated and wild species. This cluster contained three sub-clusters, representing six species; $C$. brevidens, $C$. intermedia, $C$. incana, C. deserticola, C. lanceolata, and C. trichotoma.
Table 2 The contribution of variables to the first five principal components of 83 Crotalaria accessions in Kenya

\begin{tabular}{lrrrrr}
\hline Traits & PC 1 & \multicolumn{1}{l}{ PC 2 } & \multicolumn{1}{l}{ PC 3 } & PC 4 & PC 5 \\
\hline Eigenvalue & 2.961 & 1.730 & 1.398 & 0.838 & 0.764 \\
Variance \% & 0.329 & 0.192 & 0.155 & 0.093 & 0.085 \\
Cumulative \% & 0.329 & 0.521 & 0.676 & 0.770 & 0.855 \\
Factor loading & & & & & \\
Height (cm) & 0.092 & -0.346 & 0.394 & -0.467 & 0.6803 \\
No. of leaflets & 0.379 & -0.212 & 0.232 & 0.458 & -0.1205 \\
Leaf length & -0.524 & -0.117 & 0.034 & -0.050 & -0.0489 \\
Leaf width & -0.421 & 0.158 & -0.101 & 0.342 & 0.4087 \\
Number of & -0.234 & -0.399 & 0.294 & -0.344 & -0.5601 \\
$\quad$ branches & & & & & \\
Pod length & -0.001 & -0.616 & -0.149 & 0.346 & 0.1838 \\
Pod diameter & -0.045 & -0.507 & -0.488 & 0.072 & -0.0548 \\
Pods per plant & -0.167 & -0.026 & 0.657 & 0.459 & -0.0482 \\
Leaf area & -0.558 & 0.006 & -0.013 & 0.023 & 0.0214 \\
\hline
\end{tabular}

\section{Variable-reduction by principal components}

The principal component analysis (PCA) grouped the nine quantitative traits into nine principal components, 
which accounted for all the genetic variation observed in the 83 Crotalaria accessions. The first five principal components (PCs) explain $85.5 \%$ of the observed variation in the accessions, out of which $52.1 \%$ of the variability was accounted for by the first two PCs (Table 2). The traits that contributed to the most variability among accessions both in the negative and positive loadings in the first PC1 were leaf area, leaf length, leaf width and number of leaflets. With an Eigen value of 1.73 , the second PC accounted for $19.2 \%$ of the phenomic variation. The phenotypic attributes that mainly contributed to $\mathrm{PC} 2$ were pod length, pod diameter number of branches and plant height. Pods per plant, pod diameter, and height were the traits that contributed to the variation accounted for by PC3, whose Eigen value was 1.39 .

The correlation between variables and PCs revealed that the variables height, leaf length, and leaf area are well explained by the first two PCs, since they appear at the periphery of the correlation circle. These two PCs however cannot properly explain the variables pod length and pod diameter as they appear at the center of the correlation circle (Fig. 6a). Based on this bi-plot, PCs 1 and 2 have almost no information on pods per plant but provide adequate information on diversity aspects based on leaf area and leaf length. A bi-plot on the correlation between accessions and PCs revealed a similar grouping as that of the cluster dendrogram, with the furthest accession in the bottom left quartile clustering as a distant relative of the other accessions (Fig. 6b). The bi-plots also revealed that the variables leaf area and pod length and also leaf length and height are orthogonal.
Most of the observed variation was contributed by the quantitative traits, with the qualitative traits contributing little to the clustering. The magnitude of contribution of quantitative and qualitative traits to variation as depicted by the heat maps generated based on the counties of collection (Fig. 7) and agro-ecological regions (Additional file 6: Figure S1) resonates with the PCA output. The most important quantitative traits were the number of pods per plant, the leaf area, number of branches, leaf length, and pod length. Seed colour followed by pod shape were the most contributing qualitative traits to diversity.

\section{NMDS clustering}

According to the non-metric multidimensional scaling (NMDS) analysis, the close affinities among the accessions in each sample type are supported by their proximity to one another though there is still a little morphological overlap with other samples. The NMDS ordination with a stress value of 0.165 indicated an acceptable ordination of the data. Characteristic of the sampling counties, fifteen NMDS groups were formed (Fig. 8). Similarly, six groups were formed representing the six agro-ecological sampling regions (Fig. 9). The two most significant variables that generated the clusters in the two-dimension model at $\mathrm{P}<0.05$ were number of pods per plant and leaf area index (with a score of $12 \%$ and $0.8 \%$ respectively). Based on the administrative clusters (Fig. 8), accessions collected from Kakamega county and the neighbouring counties exhibited similar morphological traits with exception of Nairobi county. A unique overlap between accessions collected in Migori and Kajiado counties was observed. Samples from Makueni
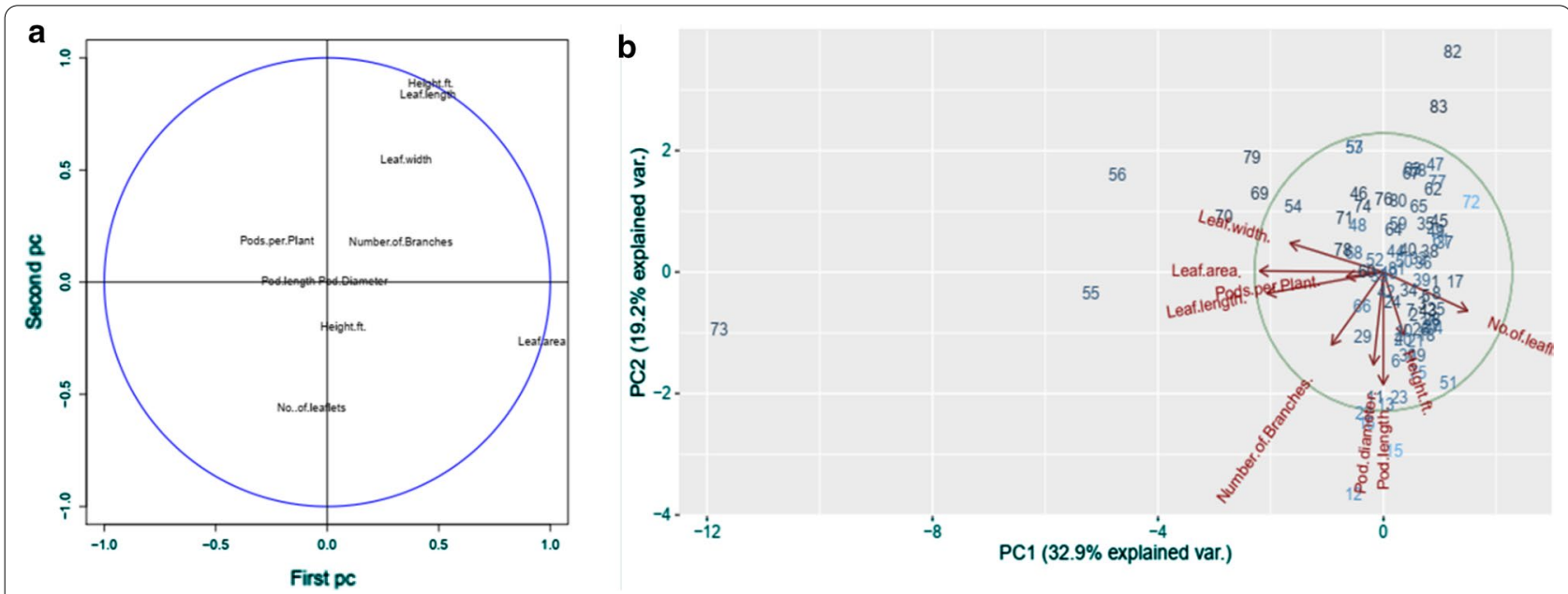

Fig. 6 a Correlation between variables and principal components, b correlation between 83 Crotalaria accessions from Kenya and principal components 


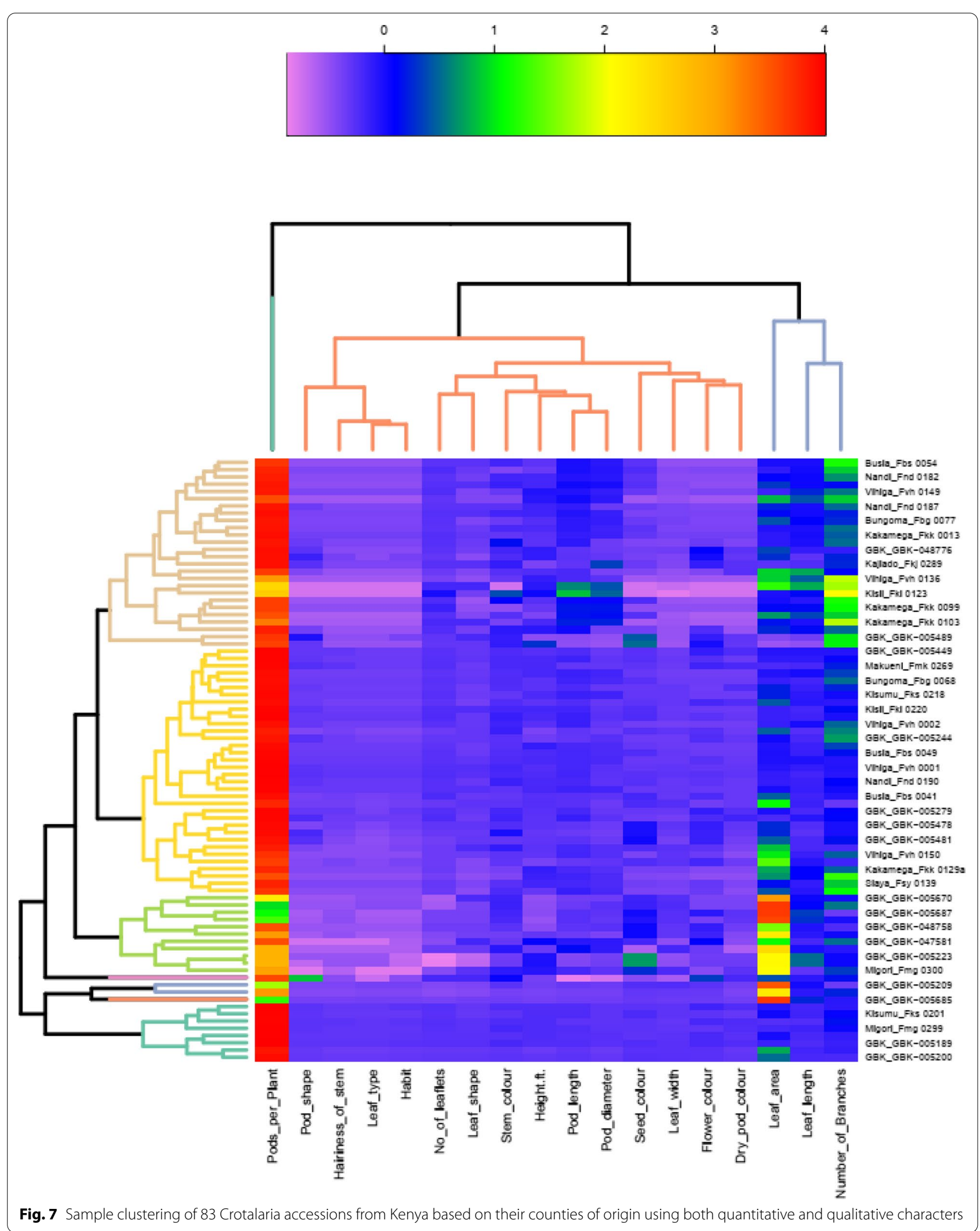




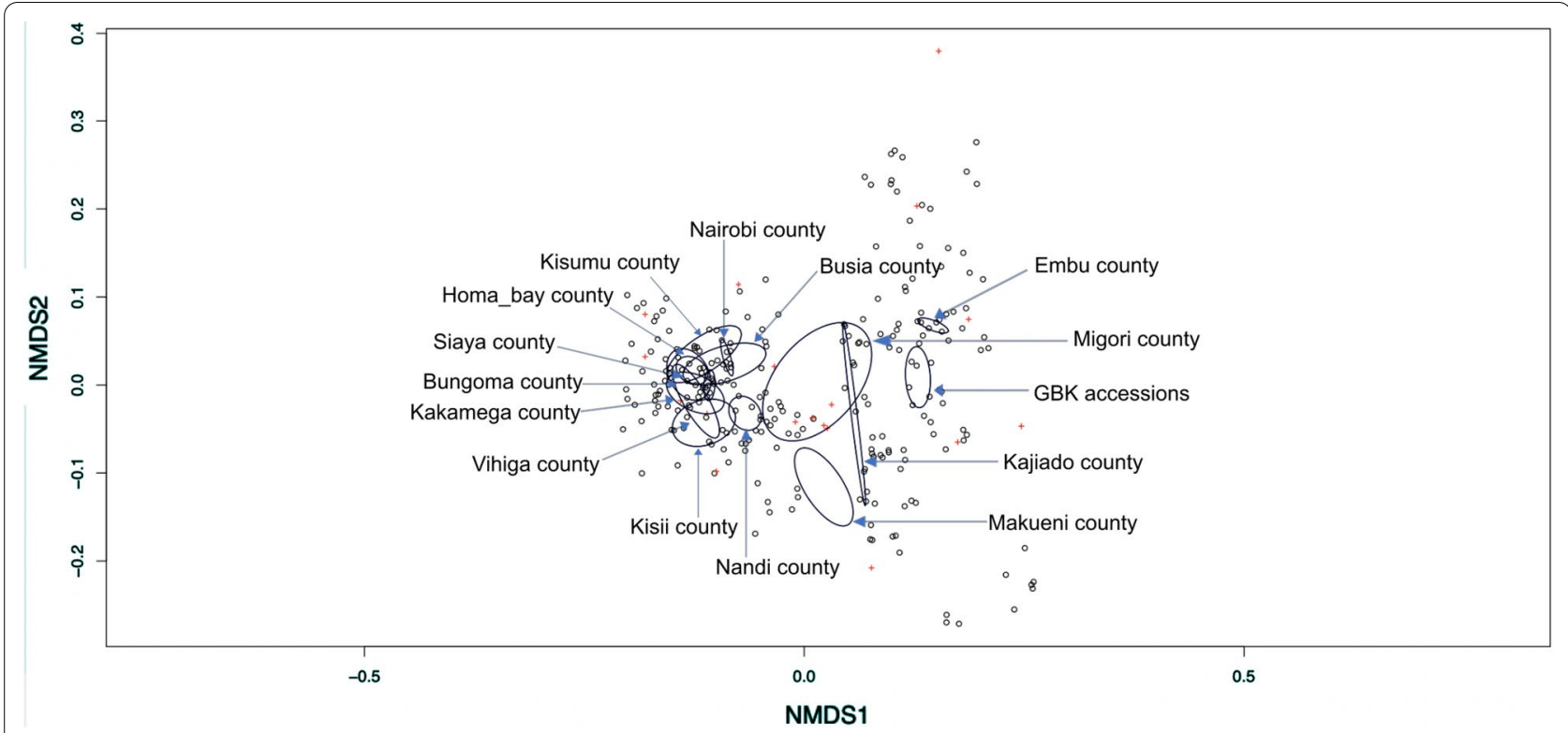

Fig. 8 Non-metric multidimensional scaling (NMDS) plot of 18 morpho-descriptors for 83 Crotalaria accessions sampled from 15 counties in Kenya

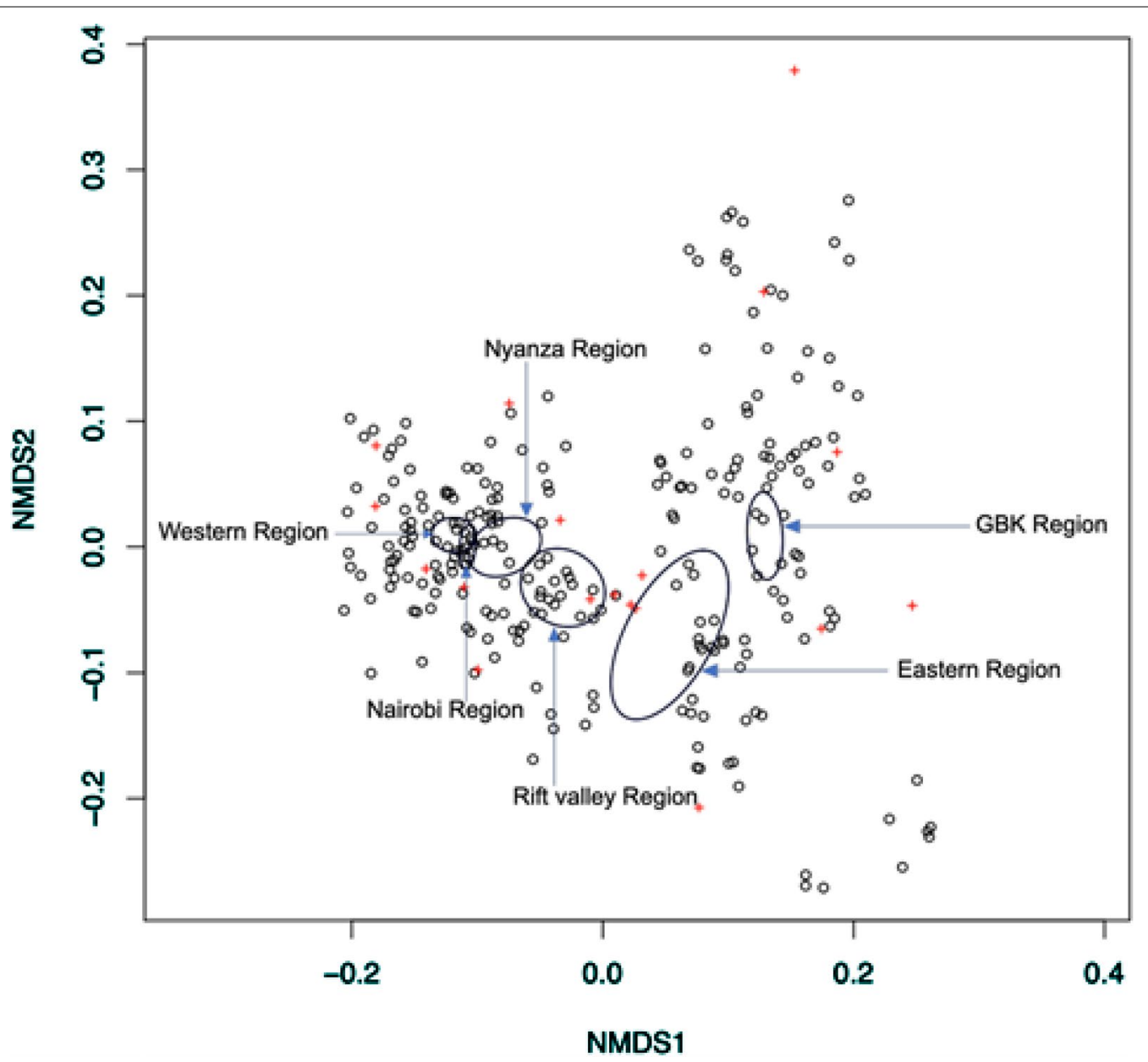

Fig. 9 Non-metric multidimensional scaling (NMDS) plot of 18 morpho-descriptors for 83 Kenyan Crotalaria accessions sampled in 6 regions 
and Embu counties as well as GBK accessions exhibited peculiar characteristics and thus showed no significant relatedness to the other accessions. Based on the agroecological regions, accessions collected from Western region and the neighbouring Nyanza and Rift valley regions exhibited similar morphological traits. Accessions collected from Nyanza region shared a noticeable proportion of similarities with accessions collected from the Rift valley region. Accessions collected from the Eastern region and gene bank exhibited peculiar characteristics thus showed no significant relatedness to the other study accessions. The ANOSIM value of $(\mathrm{R}=0.4807$, $\mathrm{P}=0.001$ ) supported the even distribution of high and low ranks within and between groups of Crotalaria species in the different counties and agro-ecological regions. Although distantly separated, the accessions from Nairobi clustered together with those from Kakamega and exhibited similar morphological appearance.

\section{Discussion}

This is the first study documenting the phenomic diversity of cultivated and wild Crotalaria species from the different agro-ecological regions in Kenya. In the present study, three Crotalaria species are reported as edible and distributed among Kenyan farmers, compared to 15 species which are reported as edible in the genus worldwide (Barrett 1990). In earlier studies, in Kenya, only two species, C. brevidens and C. ochroleuca, were reported as edible (Abukutsa-Onyango 2007). The distinction between the two varieties of $C$. brevidens and the availability of $C$. trichotoma among the Kenyan farmers are hereby reported for the first time. The edible Crotalaria species reported before was only $C$. brevidens Benth. Var brevidens although $C$. brevidens Benth. Var intermedia is more common among the Kenyan farmers. The two varieties of $C$. brevidens Benth are found in several African countries including Nigeria, Ethiopia, Kenya, Uganda and Tanzania as well as the Americas. C. ochroleuca is wide spread throughout all African countries except the north and south most parts and outside Africa in Australia, Brazil, China, New Guinea and the United States. C. trichotoma is found predominantly in East Africa, Taiwan and Vietnam (Chauvet 2004). In Kenya, the edible Crotalaria species are only common among the Luo and Luhya communities and are therefore predominantly found cultivated in the western part of the country. The preference of each of these varieties of $C$. brevidens Benth. among Kenyan farmers could be investigated further and awareness on the different species created among the farmers, consumers and breeders.

The present study reports 21 Crotalaria species present in 15 counties of Kenya, a relatively high diversity considering the high species rich mountainous regions were not sampled. However, based on the Flora of Tropical East Africa (FTEA) data, over 93 species of Crotalaria are thought to be present in Kenya (Zhou et al. 2017). This difference could be attributed to sampling time and species extinction factors. FTEA is a data base which receives contributions from many botanists and has been collecting samples since the 1940s compared to the current study which collected samples over a period of five months. In the current study only $16.2 \%$ of Crotalaria farmers had tertiary education and the crop is cultivated in small parcels of land. This indicates that the crop has been neglected and most farmers with economic resources are not planting it despite its benefits. Variability was observed in all the qualitative and quantitative traits investigated. Contrary to a previous study by Mwakha et al. (2020), who reported lack of diversity in stem colour, dry pod colour, and hairiness of the stem. The study by Mwakha et al. (2020), investigated two domesticated species hence the diversity could have been lost over time due to selection pressure. In agreement with the findings of Raj and Britto (2011), the present study established that most of the traits observed were not exclusive to a particular Crotalaria species with the leaf shape trait being among the most diverse qualitative trait. Therefore, agro-morphological characterization alone is not adequate for diversity assessment of Crotalaria and should be supported by other methods such as DNA based techniques. However, Phenomic characterization of plants can be ideal in identification of suitable morphological markers for crop improvement by breeders and researchers.

Diverse leaf/leaflet shapes including oblanceolate, elliptical, linear, obovate, orbicular and ovate were observed in current study. However, the distinctiveness of this trait in most of the cultivated species was lacking, with observations of different leaflet shapes in different plants of the same species. Overlap in leaf types in the species C. brevidens and $C$. ochroleuca which are common cultivated species in Kenya has been previously reported (Mwakha et al. 2020). Therefore, this trait may not a good qualitative parameter for inheritance studies. In all the wild accessions examined in this study, only one leaf/leaflet shape was observed per accession. This is in agreement with the findings of Soyewo and Omiyale (2015) who observed distinct leaf shapes per species in different $\mathrm{Cro}$ talaria species in Nigeria. The other trait which was also found to be inconsistent in cultivated species but consistent in wild species was seed colour. In the cultivated species C. brevidens, C. ochroleuca, and C. trichotoma, there were mixtures of different seed colours in the same pod. Most of these species had mixtures of pale yellow and red 
orange seeds, with rare cases of a uniform seed colour being observed. In the wild species, mixed seed colour was not observed in one pod. Other studies on the seed morphology of Crotalaria, have reported mixed seed colour phenomenon in different Crotalaria species (Miller 1967; Subramaniam et al. 2015). Except for inter-species crosses involving wild types and cultivated species, seed colour might also not be a good qualitative trait for species improvement.

This study reported a strong positive correlation between, leaf length and leaf area and between leaf width and leaf area. Leaf width and length being factors of leaf area would be expected to positively correlate with each other and with leaf area. This has also been observed in wheat seedlings (Zhang et al. 2015). Correlation among quantitative variables means that it is possible to improve one of them by targeting the other. Other studies also allude that strongly correlating traits are possibly under the control of same genes, and therefore when breeding, selecting for one of the traits could result in the improvement of the other trait (Neyhart et al. 2019). In the present study, other significant positive correlation was observed between leaf length and number of branches, pod length, pod diameter as well as pods per plant. This therefore could imply that some of the genes controlling the leaf parameters and those controlling pod parameters could be having a pleiotropic effect on the opposite parameters. For example, the pleiotropic control of leaf shape and the number of seeds per pod has been confirmed in soy bean mutants, and shown to be under the control of the $L n$ gene (Sayama et al. 2017). Significant correlation was also observed between the number of branches and the pod parameters; pod length, pod diameter as well as pods per plant, suggesting a possible pleiotropic relationship between the genes controlling branching and these pod parameters. This has been demonstrated in sun-flower, where the branching locus (B), has been shown to pleiotropically affect seed and capitula morphology, aspects that are closely related to pods in Crotalaria (Bachlava et al. 2010).

Cluster analysis grouped the 83 Crotalaria accessions into eight clusters. Most of the cultivated accessions clustered together while most of the wild species also clustered together. The assembly profile of most cultivated accessions could be attributed to selection pressure which is known to reduce variability in plants. The high homogeneity observed in cluster $F$ which consists of the cultivated species C. brevidens and C. ochroleuca could be largely due to unique selection pressure that aimed at improving these species as vegetables. The phenomenon of selection pressure shaping grouping in cluster analysis has been previously reported in jute mallow by Ngomuo et al. (2017). C. spectabilis in cluster A and C. intermedia in cluster $\mathrm{G}$ appeared as singletons after clustering. This means that these accessions could be having unique morphological traits which were not found in the other accessions. Similarly, singletons in a cluster dendrogram were observed by Dube et al. (2019) in different Corchorus accessions and suggested that such samples should be given more attention during selection since they are more diverse. The cluster $\mathrm{H}$ had both cultivated and wild species, suggesting that the domesticated species are closely related to these wild species. This could explain why $C$. deserticola, and C. lanceolata closely resemble C. brevidens. Morphologically similar species could also be close genetically hence such clusters can be useful in improving the cultivated varieties using the wild accessions.

The overlap of NMDS groups in some regions could be an indication of germplasm exchange, similar domestication practices and reduced epigenetic effects asserted by characteristics of the different agro-ecological zones of the study area. The domestication of some Crotalaria species by certain communities in Western and Nyanza regions of Kenya coupled with their migratory patterns to other different regions including Nairobi could have greatly contributed to the narrow diversity and similarity in morphological characteristics among accessions collected in these regions. Overlaps in NMDS groups are common observations in genetic and community structure analysis of plant populations. Closely located NMDS groups are an indication of close geographical or genetic distance between accessions as indicated by Wang et al. (2009).

In the present study, the first two principal components contributed to $52.1 \%$ of the observed variation among the accessions. This was lower than a cumulative variance of 84.3\% observed by Mwakha et al. (2020) who worked with two Crotalaria species. Leaf length, leaf width, leaf area, number of leaflets, pod length, pod diameter, number of branches and plant height were the highest contributing factors to the observed variability. These parameters therefore constitute the most important attributes for any breeder seeking to improve these species.

\section{Conclusion}

This study provides a detailed phenomic description of 21 Crotalaria species in Kenya. Whereas C. brevidens has been previously documented as an edible species in Kenya, the present study for the first time differentiates the $C$. brevidens in Kenya into distinct varieties; $C$. brevidens Benth. var. brevidens, C. brevidens Benth. var. intermedia. The study also documents $C$. trichotoma for the first time as an edible cultivated species in Kenya. Results of this study further highlight important target agronomic traits as revealed by morphological diversity 
analysis and hence serve as a reference point for genetic improvement of the cultivated Crotalaria species. The phenomic relationship profile between cultivated and wild Crotalaria species provides a baseline for novel Crotalaria breeding programs since wild species form a rich reservoir of adaptive genes. This study therefore is a critical foundation for genomic characterization of this genus.

\begin{abstract}
Abbreviations
ANOVA: Analysis of variance; GBK: Genetic Resources Research Institute of Kenya; NMDS: Non-metric multidimensional scaling; PCA: Principal component analysis; PCs: Principal components; RCBD: Randomized complete block design; UPGMA: Unweighted Pair-Group Method with Arithmetic average.
\end{abstract}

\section{Supplementary Information}

The online version contains supplementary material available at https://doi. org/10.1186/s43170-021-00031-0.

Additional file 1: Table S1. Summary information of the different samples used to study phenomic diversity of Crotalaria species in Kenya.

Additional file 2: Table S3. Summary information on the interviewed Crotalaria farmers in Kenya.

Additional file 3: Table S4. Correlation of cultivation aspects of edible Crotalaria species based on 37 sampled farmers in Kenya.

Additional file 4: Table S2. Means of quantitative variables of Crotalaria accessions from Kenya.

Additional file 5: Table S5. Cluster wise means and range values for the different traits used to study phenomic diversity of Crotalaria species in Kenya.

Additional file 6: Figure S1. Sample clustering of 83 Crotalaria accessions from Kenya based on their agro-ecological regions using both quantitative and qualitative characters.

\section{Acknowledgements}

The authors would like to thank Amanuel M. Ghilamicael for his assistance on data analysis and his valuable suggestions on the draft manuscript.

\section{Authors' contributions}

JKM, JON, and NLMB designed the experiments. JKM and JON analysed the data and wrote the manuscript. JKM performed the experiments. NLMB guided the research. NLMB, JON, PK and EO conceptualized the idea, secured funds and supervised the work. All authors read and approved the final manuscript.

\section{Funding}

This work was supported by a grant from the National Research Fund Kenya.

\section{Availability of data and materials}

All the data generated or analyzed from this study are included in this published article and its Additional files.

\section{Declarations}

Ethics approval and consent to participate

Not applicable.

\section{Consent for publication}

Not applicable.

\section{Competing interests}

The authors declare that they have no competing interests.

\section{Author details}

${ }^{1}$ Department of Biological Sciences, University of Embu, Embu, Kenya.

${ }^{2}$ Institute for Biotechnology Research, Jomo Kenyatta University of Agriculture and Technology, P.O Box 62000, 00200 Nairobi, Kenya. ${ }^{3}$ Department of Life Sciences, South Eastern Kenya University, Kitui, Kenya. ${ }^{4}$ Department of Medical Microbiology, Jomo Kenyatta University of Agriculture and Technology, Juja, Kenya.

Received: 10 December 2020 Accepted: 23 February 2021

Published online: 09 March 2021

\section{References}

Abukutsa-Onyango M. Response of Slenderleaf (Crotalaria brevidens benth) to inorganic nitrogen application. Afr J Food Agric Nutr Dev. 2007;7(3):1-10.

Bachlava E, Tang S, Pizarro G, Schuppert GF, Brunick RK, Draeger D, Leon A, Hahn V, Knapp SJ. Pleiotropy of the branching locus (B) masks linked and unlinked quantitative trait loci affecting seed traits in sunflower. Theor Appl Genet. 2010;120(4):829-42. https://doi.org/10.1007/s0012 2-009-1212-1.

Barrett RP. Legume species as leaf vegetables. In: Proceedings of the first national symposium NEW CROPS, Research, Development, Economics, Indianapolis, Indianas. 1990. p. 391-6.

Bhandari H, Bhanu AN, Srivastava K, Singh M, Shreya HA. Assessment of genetic diversity in crop plants-an overview. Plants Agric Res. 2017;7(3):279-86. https://doi.org/10.15406/apar.2017.07.00255.

Chauvet M. Plant resources of Tropical Africa. Category: vegetables (PROTA). 2004. https://uses.plantnet-project.org/en/Category:Vegetables_(PROTA).

Dube SP, Marais D, Mavengahama S, Van Jaarsveld CM, Gerrano AS. Characterisation of agro-morphological traits of corchorus accessions. Acta Agric Scand Sect B Soil Plant Sci. 2019;69(2):126-34. https://doi. org/10.1080/09064710.2018.1514419.

Fu YB. Understanding crop genetic diversity under modern plant breeding. Theor Appl Genet. 2015;128:2131-42. https://doi.org/10.1007/s0012 2-015-2585-y.

Govindaraj M, Vetriventhan M, Srinivasan M, Govindaraj M, Vetriventhan M, Srinivasan M. Importance of genetic diversity assessment in crop plants and its recent advances: an overview of its analytical perspectives. Genet Res Int. 2015;2015:1-14. https://doi.org/10.1155/2015/431487.

McCune B, Grace JB. Analysis of ecological communities. Gleneden Beach: Mjm Software Design; 2002. p. 1-12.

Miller RH. Crotalaria seed morphology, anatomy, and identification. Washington, D.C: Agricultural Research Service; 1967.

Mwakha FA, Gichimu BM, Neondo JO, Kamau PK, Odari EO, Muli JK, Budambula NLM. Agro-morphological characterization of Kenyan Slender Leaf (Crotalaria brevidens and C. ochroleuca) accessions. Int J Agron. 2020;2020:1-10. https://doi.org/10.1155/2020/2710907.

Neyhart JL, Lorenz AJ, Smith KP. Multi-trait improvement by predicting genetic correlations in breeding crosses. G3 Genes Genomes Genet. 2019;9(10):3153-65. https://doi.org/10.1534/g3.119.400406.

Ngomuo M, Stoilova T, Feyissa T, Ndakidemi PA. Characterization of morphological diversity of jute mallow (Corchorus spp.). Int J Agron. 2017;2017:112. https://doi.org/10.1155/2017/6460498.

Pandey A, Singh R, Sharma SK, Bhandari DC. Diversity assessment of useful Crotalaria species in India for plant genetic resources management. Genet Resour Crop Evol. 2010;57:461-70.

Pandey DK, Adhiguru P, Devi SV, Dobhal S, Dubey SK, Mehra TS. Quantitative assessment of crop species diversity in shifting cultivation system of Eastern Himalaya. Curr Sci. 2019;117(8):1354-7. https://doi.org/10.18520/ cs/v117/i8/1354-1357.

Plazas M, Andújar I, Vilanova S, Gramazio P, Javier Herraiz F, Prohens J. Conventional and phenomics characterization provides insight into the diversity and relationships of hypervariable scarlet (Solanum aethiopicum L.) and gboma (S. macrocarpon L.) eggplant complexes. Front Plant Sci. 2014;5(JUL):1-13. https://doi.org/10.3389/fpls.2014.00318.

Raj L, Britto S. Identification of agronomically valuable species of Crotalaria based on phenetics. Agric Biol J N Am. 2011;2(5):840-7. https://doi. org/10.5251/abjna.2011.2.5.840.847.

Raju SKK, Shao MR, Sanchez R, Xu YZ, Sandhu A, Graef G, Mackenzie S. An epigenetic breeding system in soybean for increased yield and stability. 
Plant Biotechnol J. 2018;16(11):1836-47. https://doi.org/10.1111/ pbi.12919.

Ramos MG, Villatoro MAA, Urquiaga S, Alves BJR, Boddey RM. Quantification of the contribution of biological nitrogen fixation to tropical green manure crops and the residual benefit to a subsequent maize crop using 15N-isotope techniques. J Biotechnol. 2001;91(2-3):105-15. https://doi. org/10.1016/S0168-1656(01)00335-2.

Renting H, Marsden TK, Banks J (2003) Understanding alternative food networks: exploring the role of short food supply chains in rural development. Environ Plan A Econ Space 35(3):393-411

Rouamba A, Ouédraogo V, Karama I, Compaoré M, Kiendrebeogo M. Ethno-medicinal use of Crotalaria retusa L. (Fabaceae), a pyrrolizidine alkaloid toxic plant. Int J Biochem Res Rev. 2018;23(2):1-6. https://doi. org/10.9734/ijbcrr/2018/43635.

Sadiq W, Abbasi FM, Ali H, Tariq M, Rahman IU. Evaluation of agro-morphological traits among the advance lines of rice. Acta Ecol Sin. 2019:39(2):142-4. https://doi.org/10.1016/j.chnaes.2018.08.006.

Sahou DM, Makokha AO, Sila DN, Abukutsa-onyango MO. Nutritional composition of Slenderleaf (Crotalaria ochroleuca and Crotalaria brevidens) vegetable at three stages of maturity. J Agric Food Technol. 2014:4(5):16-26.

Sayama T, Tanabata T, Saruta M, Yamada T, Anai T, Kaga A, Ishimoto M. Confirmation of the pleiotropic control of leaflet shape and number of seeds per pod by the Ln gene in induced soybean mutants. Breed Sci. 2017;67(4):363-9. https://doi.org/10.1270/jsbbs.16201.

Soyewo LT, Omiyale OA. Ecological distribution of the genus Crotalaria in Nigeria. Int J Sci Technol Res. 2015;4(8):348-55.
Subramaniam S, Pandey AK, Rather SA. Pollination of Anemopaegma album (Bignoniaceae) with focus on floral nectar as the mediator of interactions with mutualistic and antagonistic bees. Int J Plant Reprod Biol. 2015;7(2):135-46. https://doi.org/10.14787/ijprb.2015.

Wang ML, Mosjidis JA, Morris JB, Dean RE, Jenkins TM, Pederson GA. Genetic diversity of Crotalaria germplasm assessed through phylogenetic analysis of EST-SSR markers. Genome. 2006:49:707-15.

Wang ML, Zhu C, Barkley NA, Chen Z, Erpelding JE, Murray SC, Tuinstra MR, Tesso T. Pederson GA, Yu J. Genetic diversity and population structure analysis of accessions in the US historic sweet sorghum collection. Theor Appl Genet. 2009;120:13-23. https://doi.org/10.1007/s00122-009-1155-6.

Zhang L, Richards RA, Condon AG, Liu DC, Rebetzke GJ. Recurrent selection for wider seedling leaves increases early biomass and leaf area in wheat (Triticum aestivum L.). J Exp Bot. 2015;66(5):1215-26. https://doi.org/10.1093/ jxb/eru468.

Zhou Y, Liu B, Mbuni Y, Yan X, Mwachala G, Hu G, Wang Q. Vascular flora of Kenya, based on the Flora of Tropical East Africa. PhytoKeys. 2017:126(90):113-26. https://doi.org/10.3897/phytokeys.90.20531.

\section{Publisher's Note}

Springer Nature remains neutral with regard to jurisdictional claims in published maps and institutional affiliations.
Ready to submit your research? Choose BMC and benefit from:

- fast, convenient online submission

- thorough peer review by experienced researchers in your field

- rapid publication on acceptance

- support for research data, including large and complex data types

- gold Open Access which fosters wider collaboration and increased citations

- maximum visibility for your research: over $100 \mathrm{M}$ website views per year

At $\mathrm{BMC}$, research is always in progress.

Learn more biomedcentral.com/submissions 